\title{
Comparative Analysis of Enzymatic and Antioxidant Properties in Two Varieties of Clitoria ternatea
}

\author{
Moni Nishad ${ }^{1}$, Yashodhara Verma ${ }^{2}$ \\ Sam Higginbottom Institute of Agriculture, Technology and Sciences, Allahabad-211007 (UP), India
}

\begin{abstract}
The goal of the present study was to compare the enzymatic antioxidants viz., superoxide dismutase, catalase, lipid peroxidation, polyphenol oxidase, ascorbic acid oxidase and antioxidant properties in leaves and roots white flowered and purple flowered varieties of Clitoria ternatea. white flowered leaves showed higher enzymatic activity as compared to Clitoria ternatea purple flowered variety. In case of roots the purple flowered variety showed higher lipid peroxidation, superoxide dismutase and polyphenol oxidase as compared to white flowered variety. Whereas white flowered variety roots showed higher catalase and ascorbic acid oxidase activity as compared to purple flowered variety. Clitoria ternatea white flowered leaves and roots showed higher antioxidant activity as compared to purple flowered leaves and roots.
\end{abstract}

Keywords: Clitoria ternatea, enzymatic properties and antioxidants.

\section{Introduction}

Clitoriaternatea is a member of leguminoseae (Fabaceae). It is commonly called Clitoriaternatea, blue pea, butterfly pea, aparajita (India), kordofan pea (Sudan), cunha (Brazil) or pokindang (Philippines), is a vigorous, twinning summer growing, perennial legume of Old World Origin. The taxonomy, nomenclature and distribution of Clitoriaternatea have been reviewed by Fantz (1977).It is a deep rooted, tall slender and are a climbing legume. Clitoriaternateais selfpollinated however segregating genotype have been identified indicating partial out crossing probably exists. Clitoriaternatea is widely used in traditional Indian systems of medicine as a brain tonic and is believed to promote memory and intelligence. The study conducted on rats revealed that Clitoriaternatea root extracts increase rat brain acetyl choline content and acetyl choline esterase activity in a similar fashion to the standard cerebro drug pritinol (Taranalli and Cheeramkuzhy, 2003). The plant is considered as a good brain tonic and is useful for throat and eye infection, skin diseases, urinary troubles even in cattle, ulcer and antidotal properties (Malabodi and Nataraja, 2001) besides its medicinal property Clitoriaternatea is also a good source of phytochemical substances. It contains antifungal proteins and has been shown to be homologous to plant defenses (ct-AMP1) (Thevissenet al., 2000).

\section{Materials and Methods}

The plants of two Clitoriaternatea varieties (purple and white flowered) were procured from the local nursery, Civil lines, Allahabad.

Extraction of sample

The leaves and roots of two Clitoriaternatea varieties were washed under tap water separately. The fresh sample was used for antioxidant enzyme analysis. The samples used for enzyme analysis were homogenized by using different buffers.
Lipid peroxidation was measured by estimating the end product malondialdehyde as per method of Heath and Packer (1968).Antioxidant activity was determined through DPPH free radical scavenging activity method given by (Yen and Duh, 1994).The superoxide dismutase activity was assayed the method of Bauchamp and Fridovich (1971).The method followed was given by Hosetti and Frost (1994).The polyphenol oxidase activity was assayed by measuring the increase in absorbance at $420 \mathrm{~nm}$ with the oxidation of catechol as substrate according to the method given by Liu et al. (2005).The ascorbic acid oxidase activity was assayed the method of (Bruning and Mohr, 1972).

\section{Results and Discussion}

In case of leaves the maximum lipid peroxidation was found to be $22.26 \mu \mathrm{M} / \mathrm{g}$ in white flowered and $21.55 \mu \mathrm{M} / \mathrm{g}$ in purple flowered respectively, in case of roots the two varieties of Clitoriaternatea under study, purple flowered shown the maximum lipid peroxidation $27.84 \mu \mathrm{M} / \mathrm{g}$ followed by white flowered $26.20 \mu \mathrm{M} / \mathrm{g}$ The results of present study are in accordance to Becana et al. (1986) who observed the lipid peroxidation in leaves of Medicagosativa which was 119.6 nmol MDA/g dry wt and in roots was $26.2 \mathrm{nmol}$ MDA/g dry wt.

The maximum SOD activity was obtained $8.09 \mathrm{U} / \mathrm{mg}$ of protein in leaves of white flowered followed by in leaves of purple flowered $6.86 \mathrm{U} / \mathrm{mg}$ of protein respectively. Whereas in case of roots of two varieties of Clitoriaternatea the maximum activity $1.54 \mathrm{U} / \mathrm{mg}$ of protein in purple flowered and $1.05 \mathrm{U} / \mathrm{mg}$ of protein in white flowered were found. The observations made on the parameter are in agreement with those of Padmaja et al. (2011) who also observed that 7.234 $\mathrm{U} / \mathrm{mg}$ of protein in leaves of Sesbaniagrandiflora

The maximum catalase activity was obtained $71.50 \mathrm{U} / \mathrm{mg}$ of protein in leaves of white flowered followed by in leaves of purple flowered $62.94 \mathrm{U} / \mathrm{mg}$ of protein respectively. Whereas in case of roots of two varieties of Clitoriaternatea the maximum activity $14.78 \mathrm{U} / \mathrm{mg}$ of protein in white 


\section{International Journal of Science and Research (IJSR) ISSN (Online): 2319-7064 \\ Index Copernicus Value (2013): 6.14 | Impact Factor (2015): 6.391}

flowered and $13.55 \mathrm{U} / \mathrm{mg}$ of protein in purple flowered were found. The observations made on the parameter are in agreement with those of Padmaja et al. (2011) who also observed that the catalase activity $76.06 \mathrm{U} / \mathrm{mg}$ protein in leaves of Sesbania grandiflora.

The maximum polyphenpl oxidase activity was obtained $12.71 \mu \mathrm{mol} / \mathrm{g}$ in leaves of white flowered followed by in leaves of purple flowered $11.85 \mu \mathrm{mol} / \mathrm{g}$ respectively. Whereas in case of roots of two varieties of Clitoriaternatea the maximum activity $15.16 \mu \mathrm{mol} / \mathrm{g}$ in purple flowered and $14.14 \mu \mathrm{mol} / \mathrm{g}$ in white flowered were found. The results of present study are in accordance with those of Gomathiet al. (2013) who observed that the activity of polyphenol oxidase in whole parts of Evolvulusalsinoides was $6.78 \mu \mathrm{mol} / \mathrm{g}$.

The maximum ascorbic acid oxidase activity was obtained $0.494 \mathrm{U} / \mathrm{mg}$ of protein in leaves of white flowered followed by in leaves of purple flowered $0.438 \mathrm{U} / \mathrm{mg}$ of protein respectively. Whereas in case of roots of two varieties of Clitoria ternatea the maximum activity $0.378 \mathrm{u} / \mathrm{mg}$ of protein in white flowered and $0.298 \mathrm{U} / \mathrm{mg}$ of protein in purple flowered were found. Similarly results were observed by Padmaja et al. (2011) which was $0.374 \mathrm{U} / \mathrm{mg}$ protein in leaves of Sesbania grandiflora. Accordingly Singh (2012) observed $6.392 \mathrm{U} / \mathrm{mg}$ protein activity of ascorbic acid oxidase in roots of Glycyrrhizaglabra.

It was observed from the Table 2 that methanolic extract of the roots and leaves shows an increase in scavenging activity of DPPH on increasing concentration the percentage inhibition of DPPH highest in roots of white flowered varieties of Clitoriaternatea 57.10 at $400 \mu \mathrm{g} / \mathrm{ml}$ concentration as compare to roots of purple flowered verities of Clitoriaternatea $44.95 \%$ at $400 \mu \mathrm{g} / \mathrm{ml}$ concentration the percentage inhibition found in minimum leaves of purple flowered varieties of Clitoriaternatea $10.83 \%$ at $100 \mu \mathrm{g} / \mathrm{ml}$ concentration followed by $54.28 \%, 73.38 \%$ and $89.95 \%$ at200, 300, $400 \mu \mathrm{g} / \mathrm{ml}$ concentration respectively.

The lower IC50 represent the higher antioxidant activity of leaf and root extracts. Patil and Patil (2011) observed the IC50 value of methanolic extracts of roots of blue flowered varieties of Clitoriaternatea which was $492 \mu \mathrm{g} / \mathrm{ml}$ and in white flowered varieties of Clitoriaternatea which was 342 $\mu \mathrm{g} / \mathrm{ml}$. Accordingly Rabeta et al. (2013) also observed the \% inhibition of DPPH scavenging in leaves of Clitoriaternatea which was $64.67 \%$ at $25 \mu \mathrm{g} / \mathrm{ml}, 264 \%$ at $50 \mu \mathrm{g} / \mathrm{ml}, 408.67$ $\%$ at $100 \mu \mathrm{g} / \mathrm{ml}$ and $472 \%$ at $125 \mu \mathrm{g} / \mathrm{ml}$ respectively.

Table 1: Enzymatic analysis in leaves and roots of PF (Purple flowered) and WF (White flowered) varieties of Clitoria ternatea

\begin{tabular}{|c|c|c|c|c|}
\hline \multirow{2}{*}{ Enzymatic analysis } & \multicolumn{2}{|c|}{ Leaves } & \multicolumn{2}{c|}{ Roots } \\
\cline { 2 - 5 } & PF & WF & PF & WF \\
\hline Lipid peroxidation (nmol MDA/g dry wt) & $21.54 \pm 0.41$ & $22.25 \pm 0.083$ & $27.84 \pm 0.21$ & $26.20 \pm 0.21$ \\
\hline Superoxide Dismutase (U/mg protein) & $6.86 \pm 0.44$ & $8.09 \pm 0.84$ & $1.54 \pm 0.077$ & $1.05 \pm 0.035$ \\
\hline Catalase (U/mg protein) & $62.94 \pm 0.06$ & $71.50 \pm 0.72$ & $13.55 \pm 0.30$ & $14.78 \pm 0.10$ \\
\hline Polyphenol oxidase (U/mg protein) & $11.85 \pm 0.15$ & $12.71 \pm 0.16$ & $15.16 \pm 0.16$ & $14.14 \pm 0.14$ \\
\hline Ascorbic acid oxidase (U/mg protein) & $0.43 \pm 0.05$ & $0.49 \pm 0.07$ & $0.29 \pm 0.01$ & $0.38 \pm 0.02$ \\
\hline
\end{tabular}

The data have been reported as mean \pm standard deviation $(\mathrm{n}=3)$.Students T-test were used for determination of statistical significance. $\mathrm{p}<0.05$ were regarded as significant.

Table 2: Antioxidant activity in leaves and roots of two varieties of Clitoriaternatea

\begin{tabular}{|c|c|c|c|c|}
\hline $\begin{array}{c}\text { Concentration } \\
(\boldsymbol{\mu g} / \mathbf{m} \mathbf{)})\end{array}$ & \multicolumn{3}{|c|}{ \% Inhibition of DPPH radicals } \\
\hline & $\begin{array}{c}\text { Leaves of purpled } \\
\text { flowered } \\
\text { Clitoriaternatea }\end{array}$ & $\begin{array}{c}\text { Leaves of white } \\
\text { flowered } \\
\text { Clitoriaternatea }\end{array}$ & $\begin{array}{c}\text { Roots of purpled } \\
\text { flowered } \\
\text { Clitoriaternatea }\end{array}$ & $\begin{array}{c}\text { Roots of white } \\
\text { flowered } \\
\text { Clitoriaternatea }\end{array}$ \\
\hline 100 & $10.83 \pm 0.35$ & $12.95 \pm 0.03$ & $19.54 \pm 0.31$ & $26.29 \pm 0.54$ \\
\hline 200 & $54.28 \pm 0.09$ & $52.79 \pm 0.1$ & $23.73 \pm 0.45$ & $35.57 \pm 1.0$ \\
\hline 300 & $73.38 \pm 0.26$ & $81.64 \pm 0.1$ & $35.88 \pm 0.58$ & $45.92 \pm 0.28$ \\
\hline 400 & $89.95 \pm 0.26$ & $94.30 \pm 0.27$ & $44.95 \pm 2.41$ & $57.10 \pm 1.52$ \\
\hline
\end{tabular}

The data have been reported as mean \pm standard deviation $(n=3)$.Students T-test were used for determination of statistical significance. $\mathrm{p}<0.05$ were regarded as significant.

Table 3: $\mathrm{IC}_{50}$ value in ethanolic extracts of two varieties of Clitoriaternatea

\begin{tabular}{|c|c|c|}
\hline $\begin{array}{c}\text { S. } \\
\text { No. }\end{array}$ & $\begin{array}{c}\text { Leaves and roots of two varieties of } \\
\text { Clitoriaternatea }\end{array}$ & $\begin{array}{c}\mathrm{IC}_{50} \\
(\mu \mathrm{g} / \mathrm{ml})\end{array}$ \\
\hline 1. & Purple flowered leaves & 174.4 \\
\hline 2. & White flowered leaves & 189.3 \\
\hline 3. & Purple flowered roots & 424.8 \\
\hline 4. & White flowered roots & 378.3 \\
\hline
\end{tabular}

The data have been reported as mean \pm standard deviation $(n=3)$.Students T-test were used for determination of statistical significance. $\mathrm{p}<0.05$ were regarded as significant.

\section{Conclusion}

Clitoria ternatea white flowered leaves and roots showed higher antioxidant activity as compared to purple flowered leaves and roots. 


\section{References}

[1] Fantz, P.R. (1977) A monograph of the genus Clitoria(Leguminosae:Glycineae). Ph.D. dissertation, University of Floride; Gainesville, Floride.

[2] Gomathi D., Kalaiselvi M., Ravikumar G. and Uma C. (2012) Evaluation of enzymatic and non-enzymatic antioxidant potential of Evolvulusalsinoides (l.)L. Asian Journal of Pharmacology and Clinical Research 5(2).

[3] Liu H. X., Jiang W. B., Bi Y and Luo Y. B (2005) Postharvest BHT treatment induces resistance of peach fruit to infection by Penicilliumexpansum and enhances activity of fruit defence mechanisms. Postharvest Biological Technology 35: 263-269.

[4] Malabadi R.B. and K. Nataraja (2001) Shoot regeneration in leaf explants of Clitoriaternatea $\mathrm{L}$. cultured in vitro. Phytomorphology 51: 169-171.

[5] Padmaja M., Sravanthi M. andHemalatha K.P.J. (2011) Evaluation of Antioxidant Activity of Two Indian Medicinal Plants. Journal of Phytology 3(3): 86-91

[6] Patil A.P. and Patil V.R. (2011) Evaluation of in vitro antioxidant activity of seeds of blue and white flowered varieties of Clitoriaternatealinn. International Journal of Pharmacy and Pharmacological Sciences 3:(4).

[7] Rabeta M. S. and Nabil A., Z. (2013) Total phenolic compounds and scavenging activity in Clitoriaternatea and Vitexnegundolinn .International Food Research Journal 20(1): 495-500.

[8] Singh M. (2012) Comparative phytochemical \& antioxidant study of aqueous extracts of Glycyrrhizaglabra (mulethi) \&Piper longum (long pepper). International Journal of Drug Research and Technology 2(2): 203-207

[9] Taranalli A.D. and T.C. Cheeramkuzhy. (2003) Influence of Cltoriaternatea extracts on memory and cerebro cholinergic activity in rats. Pharmaceutical Biology 38:51-56

[10] Thevissen K., Osborn R.W., Achand D. P. and Brockaert W. F. (2000) Specific binding sites for an antifungal plant defensing from Dahlia (Dahlia mercki) on fungal cells are required for antifungal activity. Molecular Plant Microbe Interaction 13:54-61 